\title{
ZNAJOMOŚĆ STANDARDU OPIEKI OKOŁOPORODOWEJ PRZEZ PACJENTKI WYBRANYCH SZPITALI WOJEWÓDZTWA ZACHODNIOPOMORSKIEGO
}

\author{
KNOWLEDGE OF THE PERINATAL CARE STANDARD IN PATIENTS OF CHOSEN HOSPITALS \\ IN THE WEST POMERANIAN VOIVODESHIP
}

\author{
Marta Stanisz ${ }^{1}$, Dorota Ćwiek ${ }^{2}$ \\ ${ }^{1}$ Studenckie Koło Naukowe przy Samodzielnej Pracowni Umiejętności Położniczych \\ Pomorski Uniwersytet Medyczny w Szczecinie \\ ${ }^{2}$ Samodzielna Pracownia Umiejętności Położniczych \\ Pomorski Uniwersytet Medyczny w Szczecinie
}

DOI: http://dx.doi.org/10.20883/pielpol.2016.1

\section{STRESZCZENIE}

Cel. Głównym celem pracy było pozyskanie wiedzy na temat świadomości pacjentek w zakresie standardu opieki okołoporodowej oraz znajomości praw wynikających z Rozporządzenia Ministra Zdrowia z dnia 20 września 2012 r. w sprawie standardów postępowania medycznego przy udzielaniu świadczeń zdrowotnych z zakresu opieki okołoporodowej sprawowanej nad kobietą w okresie fizjologicznej ciąży, fizjologicznego porodu, potogu oraz opieki nad noworodkiem (Dz.U. z 2012 r., poz. 1100). Badanie przeprowadzono w wybranych szpitalach województwa zachodniopomorskiego.

Materiał i metody. Badaniem objęto grupę 154 kobiet po porodzie drogami natury. Pacjentki hospitalizowane były w: Klinice Perinatologii, Położnictwa i Ginekologii PUM w SPSK nr 1 w Policach, Klinice Położnictwa i Ginekologii PUM w SPSK nr 2 w Szczecinie, Oddziale Położniczo-Ginekologicznym w Szpitalu w Szczecinku sp. z 0.0. Badanie zostało przeprowadzone metodą sondażu diagnostycznego w okresie od 11 lipca 2014 r. do 6 lutego 2015 r.; posłużono się autorską ankietą, opracowaną na podstawie standardu opieki okołoporodowej, o którym mowa w Rozporządzeniu Ministra Zdrowia z dnia 20 września 2012 r. (...) (Dz.U. z 2012 r. , poz. 1100).

Wyniki. W trakcieobecnejciążyzapoznało sięzestandardem opieki okołoporodowej 66,0\% pacjentek ze Szpitala w Szczecinku (stanowi to istotnie wyższy odsetek niż otrzymany w SPSK1 i SPSK2, gdzie zapoznanie się z tym tematem zadeklarowała mniej więcej jedna piąta rodzących). Znajomość swoich praw wynikających z Rozporządzenia Ministra Zdrowia z dnia 20 września 2012 r. (...) zadeklarowało 88,7\% kobiet ze Szpitala w Szczecinku, 39,5\%, z SPSK2 i 33,3\% z SPSK1.

Wnioski. Znajomość standardu opieki okołoporodowej oraz świadomość pacjentek wybranych szpitali województwa zachodniopomorskiego w zakresie swoich praw są na dość niskim poziomie. Należy zatem wdrożyć działania naprawcze, przybliżające wiedzę na ten temat wśród ciężarnych.

SŁOWA KLUCZOWE: standard opieki okołoporodowej, prawa pacjenta, poród fizjologiczny, standardy medyczne.

\begin{abstract}
Aim. The main aim of the study was to gain knowledge about patients consciousness in the field of the standard of perinatal care, as well as knowledge of the law arising from the Minister of Health Regulation of 20th September 2012 on standards of medical treatment when providing medical care from the field of perinatal care to women during the period of physiological pregnancy, physiological childbirth, postpartum and newborn care (Journal of Laws from 2012, item 1100). The study was conducted in chosen hospitals of the West Pomeranian Voivodeship.

Material and methods. The study included 154 women after natural birth. The patients were hospitalized: in the Clinic of Perinatology, Obstetrics and Gynaecology PMU, Independent Public Clinical Hospital No. 1, the Clinic of Obstetrics and Gynaecology PMU, Independent Public Clinical Hospital No. 2, Obstetrics and Gynaecology Ward, Hospital in Szczecinek. The study was performed since 11th July 2014 till 6th February 2015 by means of a diagnostic survey, based on the author's questionnaire, developed on the basis of standard of perinatal care 20th September 2012.

Results. During pregnancy $66.0 \%$ of the patients from the Hospital in Szczecinek were familiarized with the standards of perinatal care (this is a substantially higher percentage than the one obtained in SPSK1 and SPSK2 where the knowledge of this subject was declared by about one-fifth of pregnant women care from the field of perinatal care exercised ov). The knowledge of rights arising from the Minister of Health Regulation on standards of treatment when providing medical care to women during the period of physiological pregnancy, physiological childbirth, postpartum and newborn care was declared by $88.7 \%$ of women from the hospital in Szczecinek, 39,5\% from SPSK2 and 33.3\% from SPSK1.

Conclusions. Knowledge of the perinatal care standard and awareness of rights among patients from hospitals in the West Pomeranian Voivodeship are very low. Actions providing that knowledge should be applied immediately.
\end{abstract}

KEYWORDS: perinatal care standard, patient's rights, physiological childbirth, medical standards. 


\section{Wprowadzenie}

We wrześniu 2012 r. w Dzienniku Ustaw scharakteryzowano najnowszy standard opieki okołoporodowej. Rozporządzenie Ministra Zdrowia z dnia 20 września 2012 r. (...) reguluje m.in. zakres świadczeń wobec noworodka i pacjentki w czasie ciąży, porodu i połogu o przebiegu fizjologicznym. Dokument ten stanowi wzór postępowania i pełni bardzo ważną funkcję w zapewnieniu właściwej opieki nad kobietami w najważniejszym okresie ich życia. Ponadto jest aktem prawnym, za którego nieprzestrzeganie grozi odpowiedzialność karna.

Wprowadzenie nowego standardu opieki okołoporodowej miało być gwarantem polepszenia jakości świadczonych usług w zakresie opieki okołoporodowej. Ujęcie standardu w formę aktu prawnego miało wpłynąć także na podejmowanie przez kobiety świadomych decyzji dotyczących opieki medycznej. Szacowano, iż wynikiem tego będzie wzrost komfortu psychicznego, poczucia kontroli oraz pozytywne doświadczenie okresu ciąży i porodu [1]. Najważniejszym rezultatem wprowadzenia standardu z perspektywy pacjentek miało być zainicjowanie zmian i uzyskanie stabilizacji w zakresie oczekiwań społeczeństwa wobec opieki okołoporodowej [2].

Wdrożenie standardu stanowi wielkie wyzwanie zarówno dla personelu medycznego szpitala, jak i pracowników administracyjnych. Kluczowym elementem jego realizacji jest także zwiększenie poziomu świadomości pacjentek. Znajomość swoich praw jest istotna, ponieważ ułatwia ich egzekwowanie. Ważną funkcję pełnią zatem osoby zajmujące się propagowaniem tej wiedzy wśród przyszłych rodziców. Inicjatywy edukacyjne organizacji pozarządowych, m.in. Fundacji Rodzić po Ludzku czy szkół rodzenia, mają na celu dotarcie do kobiet ciężarnych zainteresowanych tą problematyką.

\section{Cel pracy}

Głównym celem pracy było pozyskanie wiedzy na temat świadomości pacjentek w zakresie standardu opieki okołoporodowej oraz znajomości praw wynikających z Rozporządzenia Ministra Zdrowia z dnia 20 września 2012 r. w sprawie standardów postępowania medycznego przy udzielaniu świadczeń zdrowotnych z zakresu opieki okołoporodowej sprawowanej nad kobietą w okresie fizjologicznej ciąży, fizjologicznego porodu, połogu oraz opieki nad noworodkiem (Dz.U. z 2012 r., poz. 1100). Badanie przeprowadzono w wybranych szpitalach województwa zachodniopomorskiego.

\section{Materiał i metodyka}

Badaniem objęto grupe 154 kobiet w pierwszej i drugiej dobie po porodzie drogami natury. Pacjentki hospitalizowane były w:
- Klinice Perinatologii, Położnictwa i Ginekologii PUM w Samodzielnym Publicznym Szpitalu Klinicznym nr 1 w Policach (dalej: SPSK1),

- Klinice Położnictwa i Ginekologii PUM w Samodzielnym Publicznym Szpitalu Klinicznym nr 2 w Szczecinie (dalej: SPSK2),

- Oddziale Położniczo-Ginekologicznym w Szpitalu w Szczecinku sp. z o.o.

Badanie zostało przeprowadzone w okresie od 11 lipca 2014 r. do 6 lutego 2015 r. Uzyskano pisemną zgodę kierowników powyższych oddziałów na realizację projektu badawczego. Pacjentki biorące udział w badaniu zostały poinformowane o jego celu oraz wyraziły ustną zgodę na uczestnictwo. Kryterium włączenia do badania stanowił poród drogami natury, poprzedzony ciążą o przebiegu fizjologicznym.

Badanie zostało przeprowadzone metodą sondażu diagnostycznego; posłużono się autorską ankietą, opracowaną na podstawie standardu opieki okołoporodowej, o którym mowa w Rozporządzeniu Ministra Zdrowia z dnia 20 września 2012 r. (...) (Dz.U. z 2012 r., poz. 1100). Ankieta zawierała pytania o charakterze zamkniętym i półotwartym.

Obliczenia statystyczne wykonano w programie Statistica 10. Badanie zależności pomiędzy zmiennymi ze względu na ich jakościowy charakter wykonano za pomocą testu niezależności chi-kwadrat Pearsona. W przypadku braku spełnienia podstawowych założeń testu (liczności oczekiwane mniejsze od 5) stosowano poprawkę Yatesa na ciągłość testu chi-kwadrat. Wyniki zaprezentowano za pomocą tabel dwudzielczych. Przyjęto poziom istotności równy 0,05, co w praktyce oznacza następujący układ hipotez:

- $\quad \mathrm{HO}$ - brak statystycznie istotnych zależności między badanymi zmiennymi ( $p>0,05)$,

- $\quad \mathrm{H} 1$ - występuje statystycznie istotna różnica między badanymi zmiennymi $(p<0,05)$.

\section{Wyniki}

Liczba posiadanego potomstwa, wiek, miejsce zamieszkania, stan cywilny oraz poziom wykształcenia - te cechy różnicowały pacjentki uczestniczące w badaniu. W tabeli 1 przedstawiono ogólną charakterystykę badanej populacji. Dla 40,3\% kobiet był to poród pierwszego dziecka, natomiast aż 59,7\% pacjentek rodziło drugie lub kolejne dziecko. Najmłodsza kobieta z grupy badanej miała 18 lat, natomiast najstarsza - 42 lata. Średnia wieku pacjentek wynosiła 29 lat. Najliczniejszą grupę reprezentowały rodzące pomiędzy 26. a 30. rokiem życia - aż 36,4\% ogółu. Pacjentki pomiędzy 31. a 35. rokiem życia stanowiły $29,2 \%$ badanej populacji, natomiast kobiety do 25 . roku życia - 24,7\%. Najmniej 
liczną grupę reprezentowały kobiety powyżej 36 . roku życia - jedynie 9,7\%. Na podstawie analizy miejsca zamieszkania wykazano, iż spośród wszystkich badanych aż 78,6\% stanowiły mieszkanki miast. Jedynie 21,4\% kobiet zamieszkiwało wsie. Większość kobiet z omawianej grupy była osobami niezamężnymi - aż 59,7\%. Pozostałe 40,3\% pacjentek było mężatkami. Wśród połowy $(50,0 \%)$ badanej populacji dominowało wykształcenie wyższe, następnie w 34,4\% - wykształcenie średnie. Najmniej liczną grupe stanowiły kobiety z wykształceniem podstawowym lub zawodowym - 15,6\%.

Tabela 1. Charakterystyka badanej grupy Table 1. Characteristic of the examined group

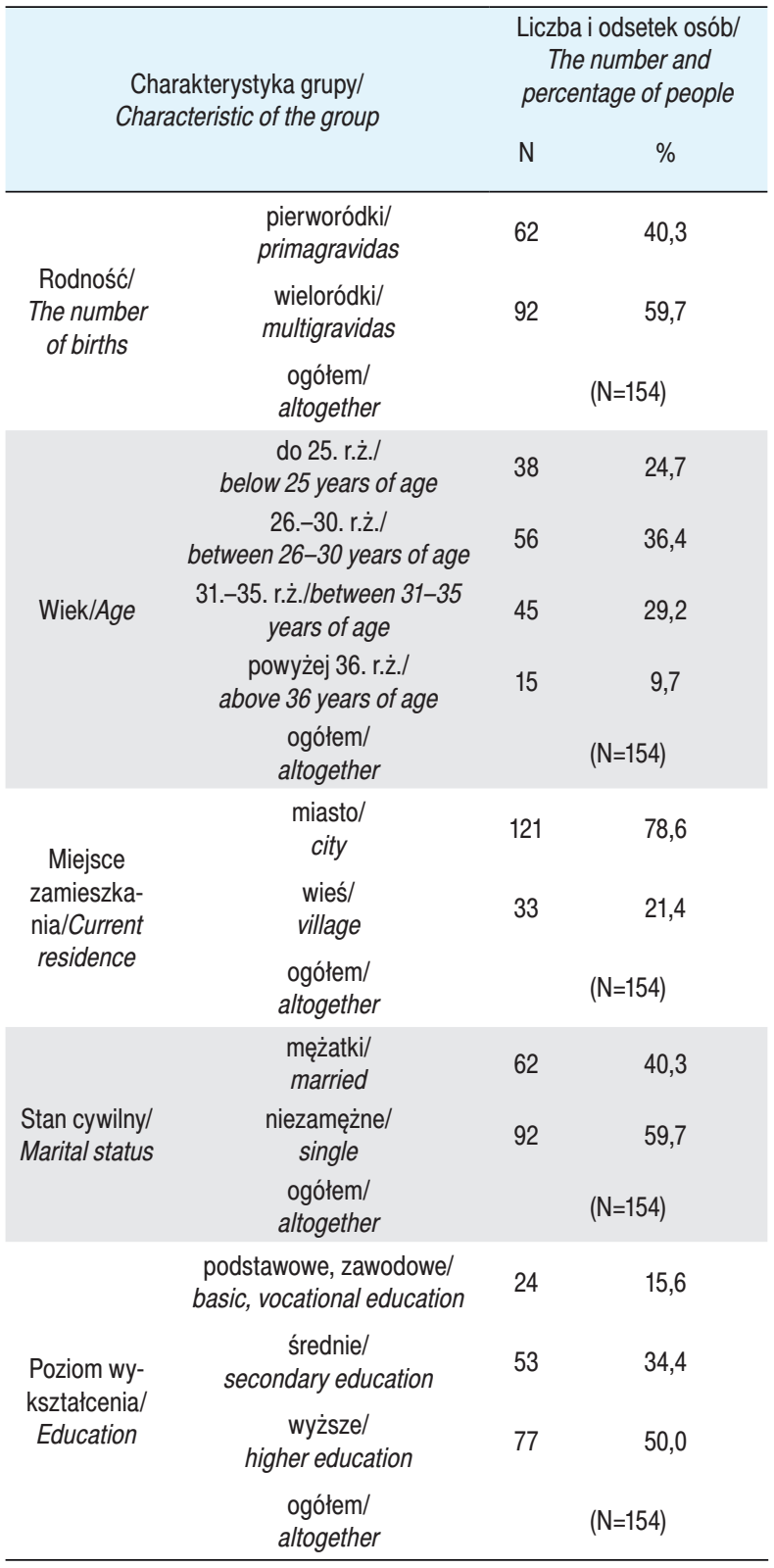

Źródło: opracowanie własne

Source: author's own analysis
Zmienną, która miała najistotniejsze znaczenie w kontekście znajomości standardu opieki okołoporodowej przez kobiety, stanowiło miejsce porodu. W tabeli 2 przedstawiono liczebność respondentek korzystających z usług poszczególnych szpitali w trakcie porodu. Spośród 154 kobiet większość, bo aż 40,9\%, rodziła w Klinice Perinatologii, Położnictwa i Ginekologi w SPSK1 w Policach PUM. Pacjentki rodzące w Oddziale Położniczo-Ginekologicznym Szpitala w Szczecinku sp. z o.o. stanowiły $34,4 \%$ badanej populacji. Najmniejszą grupe - jedynie 24,7\% - reprezentują kobiety rodzące w Klinice Położnictwa i Ginekologii SPSK2 w Szczecinie PUM.

Tabela 2. Liczebność respondentek względem poszczególnych szpitali Table 2. The number of respondents in terms of particular hospitals

\begin{tabular}{ccc}
\hline Szpital/Hospital & N & $\%$ \\
\hline SPSK1 & 63 & 40,9 \\
SPSK2 & 38 & 24,7 \\
Szpital w Szczecinku/ & 53 & 34,4 \\
Hospital in Szczecinek & 154 & 100,0 \\
\hline Ogółem/Altogether & & \\
\hline
\end{tabular}

Źródło: opracowanie własne

Source: author's own analysis

Stopień znajomości najnowszego standardu opieki okołoporodowej wśród pacjentek poszczególnych szpitali przedstawiono $\mathrm{w}$ tabeli 3. Na poziomie istotności 0,05 zaobserwowano statystycznie istotną $(p=0,000)$ zależność pomiędzy zapoznaniem się ze standardem a szpitalem, w którym rodziła pacjentka. Większość badanych kobiet ze Szpitala w Szczecinku (66,0\%) zadeklarowała, iż w trakcie obecnej ciąży zapoznała się ze standardem opieki okołoporodowej. Wśród kobiet rodzących w SPSK1 i SPSK2 jedynie około 20,0\% kobiet potwierdziło znajomość rozporządzenia.

Tabela 3. Znajomość standardu opieki okołoporodowej przez pacjentki Table 3. Knowledge of standard of perinatal care patients

\begin{tabular}{|c|c|c|c|c|c|c|}
\hline \multirow{3}{*}{$\begin{array}{c}\text { Znajomość standardu } \\
\text { opieki okołoporodowej/ } \\
\text { Knowledge of the perinatal } \\
\text { care standard }\end{array}$} & \multicolumn{6}{|c|}{ Szpital/Hospital } \\
\hline & \multicolumn{2}{|c|}{$\begin{array}{l}\text { SPSK2 } \\
(\mathrm{N}=38)\end{array}$} & \multicolumn{2}{|c|}{$\begin{array}{l}\text { SPSK1 } \\
(\mathrm{N}=63)\end{array}$} & \multicolumn{2}{|c|}{$\begin{array}{c}\text { Szpital } \\
\text { w Szczecinku } \\
(\mathrm{N}=53)\end{array}$} \\
\hline & $\mathrm{N}$ & $\%$ & $\mathrm{~N}$ & $\%$ & $\mathrm{~N}$ & $\%$ \\
\hline Tak/Yes & 9 & 23,7 & 13 & 20,6 & 35 & 66,0 \\
\hline \multirow[t]{2}{*}{ Nie/No } & 29 & 76,3 & 50 & 79,4 & 18 & 34,0 \\
\hline & \multicolumn{2}{|c|}{$\operatorname{chi}^{2}$} & \multicolumn{2}{|c|}{$d f$} & \multicolumn{2}{|c|}{$p$} \\
\hline chi $^{2}$ Pearsona & \multicolumn{2}{|c|}{29,3} & \multicolumn{2}{|c|}{$d f=2$} & \multicolumn{2}{|c|}{$p=0,000$} \\
\hline
\end{tabular}

Źródło: opracowanie własne

Source: author's own analysis 
W tabeli 4 zaprezentowano znajomość praw pacjenta wynikających z Rozporządzenia Ministra Zdrowia z dnia 20 września 2012 r. (...) przez pacjentki poszczególnych szpitali. Na poziomie istotności 0,05 zaobserwowano statystycznie istotną ( $p=0,000)$ zależność między znajomością swoich praw a szpitalem, w którym rodziła kobieta. Znajomość swoich praw wynikających z rozporządzenia, o którym mowa, zadeklarowało 88,7\% kobiet w Szpitalu w Szczecinku. Jest to istotnie wyższy odsetek w porównaniu z SPSK2 (39,5\%) oraz SPSK1 (33,3\%).

Tabela 4. Znajomość praw pacjenta wynikających z Rozporządzenia Ministra Zdrowia (...) w sprawie standardów postępowania medycznego przy udzielaniu świadczeń zdrowotnych z zakresu opieki okotoporodowej sprawowanej nad kobietą w okresie fizjologicznej ciąży, fizjologicznego porodu, połogu oraz opieki nad noworodkiem

Table 4. Knowledge of patient's rights resulting from the Minister of Health Regulation on standards of medical treatment when providing medical care from the field of perinatal care to women during the period of physiological pregnancy, physiological childbirth, postpartum and newborn care

\begin{tabular}{|c|c|c|c|c|c|c|}
\hline \multirow{3}{*}{$\begin{array}{l}\text { Zna swoje prawa/ } \\
\text { Knowledge of rights }\end{array}$} & \multicolumn{6}{|c|}{ Szpital/Hospital } \\
\hline & \multicolumn{2}{|c|}{$\begin{array}{l}\text { SPSK2 } \\
(\mathrm{N}=38)\end{array}$} & \multicolumn{2}{|c|}{$\begin{array}{l}\text { SPSK1 } \\
(\mathrm{N}=63)\end{array}$} & \multicolumn{2}{|c|}{$\begin{array}{c}\text { Szpital } \\
\text { w } \\
\text { Szczecinku } \\
(\mathrm{N}=53)\end{array}$} \\
\hline & $\mathrm{N}$ & $\%$ & $\mathrm{~N}$ & $\%$ & $\mathrm{~N}$ & $\%$ \\
\hline Tak/Yes & 15 & 39,5 & 21 & 33,3 & 47 & 88,7 \\
\hline \multirow[t]{2}{*}{$\mathrm{Nie} / \mathrm{No}$} & 23 & 60,5 & 42 & 66,7 & 6 & 11,3 \\
\hline & \multicolumn{2}{|c|}{$\mathrm{chi}^{2}$} & \multicolumn{2}{|c|}{ df } & \multicolumn{2}{|c|}{$\mathrm{p}$} \\
\hline chi ${ }^{2}$ Pearsona & \multicolumn{2}{|c|}{39,7} & \multicolumn{2}{|c|}{$d f=2$} & \multicolumn{2}{|c|}{$p=0,000$} \\
\hline
\end{tabular}

Źródło: opracowanie własne

Source: author's own analysis

W tabeli 5 przedstawiono liczebność pacjentek, które przygotowały swój plan porodu z uwzględnieniem szpitala, w którym rodziły. Na poziomie istotności 0,05 zaobserwowano statystycznie istotną $(p=0,000)$ zależność między przygotowaniem planu porodu a szpitalem, w którym rodziły pacjentki. W porównaniu z SPSK2 $(28,9 \%)$ i SPSK1 $(17,5 \%)$ istotnie statystycznie wyższy odsetek kobiet ze Szpitala w Szczecinku $(81,1 \%)$ przygotował swój plan porodu.

Tabela 5. Przygotowanie planu porodu przez pacjentki z poszczególnych szpitali

Table 5. Preparing a birth plan by patients from particular hospitals

\begin{tabular}{|c|c|c|c|c|c|c|}
\hline \multirow{3}{*}{$\begin{array}{c}\text { Przygotowanie } \\
\text { planu porodu/ } \\
\text { Preparing a birth plan }\end{array}$} & \multicolumn{6}{|c|}{ Szpital/Hospital } \\
\hline & \multicolumn{2}{|c|}{$\begin{array}{l}\text { SPSK2 } \\
(\mathrm{N}=38)\end{array}$} & \multicolumn{2}{|c|}{$\begin{array}{l}\text { SPSK1 } \\
(\mathrm{N}=63)\end{array}$} & \multicolumn{2}{|c|}{$\begin{array}{c}\text { Szpital } \\
\text { w } \\
\text { Szczecinku } \\
(\mathrm{N}=58)\end{array}$} \\
\hline & $\mathrm{N}$ & $\%$ & $\mathrm{~N}$ & $\%$ & $\mathrm{~N}$ & $\%$ \\
\hline Tak/Yes & 11 & 28,9 & 11 & 17,5 & 43 & 81,1 \\
\hline \multirow[t]{2}{*}{ Nie/No } & 27 & 71,1 & 52 & 82,5 & 10 & 18,9 \\
\hline & \multicolumn{2}{|c|}{$\mathrm{chi}^{2}$} & \multicolumn{2}{|c|}{ df } & \multicolumn{2}{|c|}{$p$} \\
\hline chi $^{2}$ Pearsona & \multicolumn{2}{|c|}{51,5} & \multicolumn{2}{|c|}{$d f=2$} & \multicolumn{2}{|c|}{$p=0,000$} \\
\hline
\end{tabular}

Źródło: opracowanie własne

Source: author's own analysis

\section{Dyskusja}

Obserwowany od wielu lat wzrost świadomości polskich kobiet w zakresie praw pacjenta przyczynia się do niespiesznego polepszania jakości opieki sprawowanej w oddziałach położniczych i salach porodowych. Niestety, w wielu przypadkach znajomość ustaw i rozporządzeń wśród pacjentów przewyższa wiedzę osób wykonujących zawody medyczne, co znacznie umniejsza profesjonalne sprawowanie obowiązków zawodowych [3]. Zmiana mentalności ludzkiej i propagowanie w społeczeństwie postrzegania porodu jako wydarzenia rodzinnego i wielowymiarowego wymusza reorganizację pracy w wielu placówkach leczniczych. Nie każdy szpital jest jednak otwarty i przygotowany na zmiany, które przewiduje ustawowo Rozporządzenie Ministra Zdrowia z dnia 20 września 2012 r. (...).

W badaniach własnych wykazano, iż znajomość standardu opieki okołoporodowej wśród pacjentek wybranych szpitali na terenie województwa zachodniopomorskiego nie była powszechnym zjawiskiem. W trakcie obecnej ciąży zapoznało się ze standardem opieki okołoporodowej 66,0\% pacjentek ze Szpitala w Szczecinku (stanowi to istotnie większy odsetek niż otrzymany w szczecińskich szpitalach klinicznych, gdzie zapoznanie się z tym tematem zadeklarowało około 20,0\% rodzących). Nieco większa wydaje się być natomiast świadomość w zakresie praw pacjenta wynikających z omawianego rozporządzenia. Znacząca większość rodzących ze Szpitala w Szczecinku wyraziła znajomość swoich praw wynikających z tego rozporządzenia; to samo zadeklarowały: jedna trzecia pacjentek z SPSK1 oraz dwie piąte kobiet z SPSK2. Potwierdzenie badań własnych stanowi raport z prac przeprowadzonych przez Fundację Rodzić po Ludzku w 2013 r. na terenie województwa mazowieckiego; według tego raportu na 30 badanych kobiet tylko 5 zadeklarowało, iż zna rozporządzenie, natomiast 5 innych przyznało, iż słyszały o tym dokumencie. Pozostałe pacjentki nie wiedziały, czym jest standard opieki okołoporodowej i jakie prawa wynikają z Rozporządzenia Ministra Zdrowia z dnia 20 września 2012 r. (...) [3]. Sugeruje to, iż problem niewiedzy dotyczył nie tylko populacji rodzących w badanym województwie zachodniopomorskim, lecz także w innych regionach Polski.

Rzadkim zjawiskiem było także przygotowywanie przez pacjentki planu porodu. Odsetek kobiet posiadających swój plan był rażąco rozbieżny w poszczególnych szpitalach województwa zachodniopomorskiego. Badania własne wykazały, iż większość rodzących w szczecińskich szpitalach - 71,1\% hospitalizowanych w SPSK2 i 82,5\% w SPSK1 - nie posiadała planu porodu. Potwierdzenie badań własnych stanowią donie- 
sienia Ćwiek, ówczesnego konsultanta wojewódzkiego w dziedzinie pielęgniarstwa ginekologiczno-położniczego, na temat realizacji standardu opieki okołoporodowej w województwie zachodniopomorskim. Zgodnie ze sprawozdaniami z lat 2011, 2012 i 2013 mniej niż $25 \%$ pacjentek przybywało do szpitala z własnym planem porodu [4-6]. Wysoki odsetek kobiet ze Szpitala w Szczecinku posiadających plan $(81,1 \%)$ wynika z faktu, iż rodzące miały możliwość wypełnienia tego dokumentu w warunkach sali porodowej. Karta planu porodu została opracowana wewnętrznie przez zespół pracowników szpitala i jest dostępna dla każdej nowo przyjętej rodzącej w tej placówce. Odniesienie do badań własnych stanowi także monitoring Fundacji Rodzić po Ludzku, z którego wynika, iż w wielu szpitalach plan porodu był zjawiskiem sporadycznie spotykanym. Według personelu większości szpitali województwa mazowieckiego z własnym planem porodu przychodzą do szpitala średnio 2-3 pacjentki w skali półtorarocznej [3]. Nieczęste korzystanie z prawa do przygotowania planu porodu sugeruje niewiedzę panującą wśród kobiet dotyczącą tej i innych możliwości będących składowymi standardu [7]. Nie bez znaczenia jest także pejoratywny sposób postrzegania idei planu porodu przez personel sal porodowych [3].

\section{Wnioski}

Znajomość standardu opieki okołoporodowej oraz świadomość pacjentek wybranych szpitali województwa zachodniopomorskiego w zakresie swoich praw są na dość niskim poziomie. Należy zatem wdrożyć działania naprawcze, przybliżające wiedzę na ten temat wśród ciężarnych.

\section{Piśmiennictwo}

1. Niepytalski K. Standardy opieki okołoporodowej. Nowości czy status quo? Forum Położnictwa i Ginekologii. 2013; 6: 59-61.
2. Karkowska D. Nowe standardy opieki nad matką i dzieckiem w kontekście prawnej organizacji opieki w Polsce. Warszawa: Fundacja Rodzić po Ludzku; 2013.

3. Kubicka-Kraszyńska U (red.). Monitoring wdrażania nowych standardów okołoporodowych w wybranych placówkach położniczych województwa mazowieckiego. Raport. Warszawa: Fundacja Rodzić po Ludzku; 2013.

4. Ćwiek D. Sprawozdanie z funkcjonowania zawodu położnej w województwie zachodniopomorskim w 2011 roku. Szczecińska Izba Pielęgniarek i Położnych @) 2011, http://www. sipip.szczecin.pl/userfiles/file/sprawozdanie8.pdf (data dostępu: 12.04.2015).

5. Ćwiek D. Sprawozdanie z funkcjonowania zawodu położnej w województwie zachodniopomorskim w 2012 roku. Szczecińska Izba Pielęgniarek i Położnych (c) 2012, http://sipip. szczecin.pl/opinie-i-sprawozdania-konsultanta-w-dziedziniepielegniarstwa-ginekologiczno-polozniczego-2// (data dostępu: 12.04.2015).

6. Ćwiek D. Sprawozdanie z funkcjonowania zawodu położnej w województwie zachodniopomorskim w 2013 roku. Szczecińska Izba Pielęgniarek i Położnych (C) 2013, http://sipip. szczecin.pl/opinie-i-sprawozdania-konsultanta-w-dziedziniepielegniarstwa-ginekologiczno-polozniczego-2/ (data dostępu: 12.04.2015).

7. Krówka D, Żur A. Kwalifikacje zawodowe położnych a standard opieki okołoporodowej. Ginekol Położ. 2013; 8 (4): 74-79.

Artykuł przyjęty do redakcji: 31.08 .2015

Artykuł przyjęty do publikacji: 16.11.2015

Źródło finansowania: Praca nie jest finansowana z żadnego źródła. Konflikt interesów: Autorzy deklarują brak konfliktu interesów.

Adres do korespondencji:

Dorota Ćwiek

ul. Żołnierska 48

71-210 Szczecin

tel.: 914800977

e-mail: dorota.cwiek@pum.edu.pl

Samodzielna Pracownia Umiejętności Położniczych

Pomorski Uniwersytet Medyczny w Szczecinie 